Huygens contra Calckman en vice-versa

Author(s): A. J. Servaas Van Rooyen and Jan Janz. Calckman

Source: Tijdschrift der Vereeniging voor Noord-Nederlands Muziekgeschiedenis, Deel 9, 3de Stuk (1912), pp. 170-173

Published by: Koninklijke Vereniging voor Nederlandse Muziekgeschiedenis

Stable URL: http://www.jstor.org/stable/947558

Accessed: $20 / 06 / 2014$ 23:03

Your use of the JSTOR archive indicates your acceptance of the Terms \& Conditions of Use, available at http://www.jstor.org/page/info/about/policies/terms.jsp

JSTOR is a not-for-profit service that helps scholars, researchers, and students discover, use, and build upon a wide range of content in a trusted digital archive. We use information technology and tools to increase productivity and facilitate new forms of scholarship. For more information about JSTOR, please contact support@jstor.org. 


\section{HUYGENS CONTRA CALCKMAN EN VICE-VERSA}

DOOR

\section{A. J. SERVAAS VAN ROOYEN.}

Het bekende boekje van Constantisn Huygens over 't gebruik en ongebruik van 't orgel in de kerken, uitgegeven in 1641, lokte verzet uit, inzonderheid van zekeren Calckman in den Haag.

Ter Huygens-tentoonstelling ${ }^{1}$ ) was niet alleen de 1 ste druk aanwezig, maar waren ook een paar latere drukken van 1659 en 1660 , die alle ter Koninklijke Bibliotheek gevonden worden.

Bij het exemplaar van den eersten druk zijn het tegenschrift van GaLckman gevoegd, alsmede eenige brieven en een brochure, welke vóór de zaak zijn.

Waar we dit alles dus bekend mogen achten, zal minder bekend zijn het ageeren van Huygens tegen Calckman, waartoe hij den kerkeraad in den arm nam. Het genotuleerde daarover nemen we in extenso over:

\section{November 1641.}

„Den Heer $\mathrm{V}_{\mathrm{AN}}$ Sullichem heeft zig by verscheidene Leeden van den E. Kerkenraad beklaagd, dat zeker CaLcKman een boekjen heeft geschreeven tegens het boekjen, geintituleerd Het gebruik of ongebruik van ' $t$ orgel in de kerken der vereenigde Nederlanden daer in zyn E. dapper werd geinjurieerd, versoekende dat d'E kerkenraad daer op gelieve te letten tot voorstand van zijne Leere; is goedgevonden, dat elk Lid van de vergaedering het Boekje zal doorleezen en het geene daer in strafwaardig word gevonden aan te tekenen, om de naeste vergaederinge na

1) Zie den Catalogus op bl 30, onder de nommers 237-239. 
behooren daer op te letten. Middeler wijlen zullen D. Triguandius, D. Sthreso en Hondios met Calckman spreeken en onderstaan of hij zig niet bewust en vind, van zig ter verr' in dat genoemde Schrift vergeeten te hebben. Sal ook by de naaste vergaderinge de zaake van den drukker Aert Meurs geexamineerd worden.

\section{Den 6 December.}

Deputati ad Causam hebben gerapporteerd dat CaLckman op haare aanspraake en instantelyk bericht, rondelyk en met traanen heeft bekend, dat hij door iver weggerukt zynde verscheide dingen heeft gesteld die hem Leed waeren, en wenschen niet gesteld te hebben. Daerop heeft D. Lootius een Narre gedaen van de meeninge van den Heere van Sullichem, als dat Z.E. zig niet wilde aantrekken de opinie van 't orgel Laetende elk zijn oordeel, maer dat, in de manieren van doen, veel dingen strafwaardig waaren, daer in zijn $\mathrm{E}$. zig geerne het oordeel van den Kerkenraad wilde submitteeren. Heeft ook D. Lotius andere grieven gemoveerd, raekende de satisfactie te doen aan naburige Kerken, Synoden, Praedikanten, en zyn E. W. int particulier als zynde geweest Lid der Synod. Delph. 1638 en om welk alles weg te neemen is, na deliberatie, eenpaeriglyk verstaen, dat D. Cabeluauw, Triglandius en Hondius een formulier of acte van schuldbekenninge zulle concipieren en dat Concept met den Heer Vav Suylichem en andere Doleanten te Communiceren, om naderhand rapport aan de E. kerkenraad gedaan zynde, te doen als bevonden zal werden tot stichtinge te behooren.

Den 20 December 1611 Is geleezen het Concept van schuldbekenninge en met eenpaarige stemmen geapprobeerd en luid van woord tot woord als volgd:

Also eenigen tyd herwaards in Consideratie is gekomen, wat van het Orgelspeelen onder het Psalmzingen in de kerke zy te houden, zo is ' $t$ dat den kerkenraad eenstemmelyk haer deesen aangaende conformeerende met het oordeel en de uitspraake der Synodie van Zuid-Holland 1638 gehouden tot Delft art. 50, verklaarende het zelve te zyn eene middelmatige zaake, te meer, dewyle zulks zo word gelaaten in de vryheid van yder kerke, dat met eenen werd gestatueerd, daer inne niet te doen, als tot stichtinge van dezelve; oversulks wel hadden gewenscht dat een 
yder Lidmaat deezer Gemeente daer inne ook hadde geacquieseerd, ofte voor het toekomende nog acquiesceerden. Ende alhoewel den Kerkenraad niet en mag nogte ook wil Imants vrijheid praejudiceeren om omtrent middelmatige zaeken van het gemeen gevoelen zeedelyk te dissentieren so en kan evenwel dezelve zonder berispinge niet voor by gaan zeker Boeksken handelende van deese materie, geintituleerd Antidotum Tegengift van 't gebruik of misbruik van 't orgel in de kerken der vereenigde nederlanden, onlangs uitgegeeven door J. J Calckman als waar inne den Kerkenraad voorbygaande de zaake zelf omtrent de maniere van dien verscheydene poincten Censurabel heeft gevonden ende bij deesen verklaard als

1. Dat J. J. Calckman dit Boeksken handelende van een theologische materie, heeft uitgegeeven zonder dat het zelve volgens de wel gefundeerde resolutie des Synodes alvorens was gevisiteerd.

2. Dat hy fol. $92 \& 93$ ende elders niet alleenlyk het oordeel der Synode van Zuid-Holtand 1638 gehouden tot Delft praesumptivelyk Condemneerd ende haere meyningen en woorden te verre uitbreid maar ook de particuliere Leeden van die voorsz. vergaaderinge zo hatelyk scheld als de openbaare Despoteurs ende geslaege vyanden van de kerke naauwlyks ooit meerder hebben gedaen.

3. Dat hy hebbende zyn gevoelen van deeze zaeke de kercken en Magistraaten van zeer veele plaetschen niet alleen in maar ook buiten deese Provincie, die hebbende de practyck van het orgel bovengemeld. den Heere veelmael oprechtelyk in eene zuyveren godsdienst zoeken te behaegen zoo meesterlyk veroordeeld, ende gennegzaem als afgodendienaers uitkreit

4. Dat hy deese materie zo verhandeld, dat hij daer in geen kleyne anleydinge geeft tot een zorgerlyke verdeeldheid en schaedelyke scheuringe in de goede gemeente, gewag makende van Gemeente ende ge meente van orgelisten ende contraorgelisten etc.

5. Dat hy in 't byzonder voorgenoomen hebbende te wederleggen het Boekxken van den Ed. Heere van Sulrchem, onlangs te vooren op deese materie uitgegeeven niet alleenlyk des zelvs meininge in verscheide passagien omstandelyk misduid ende verdraaid, maar ook dien zelven Heer doorgaans zeer bitterlijk, tegens alle Christelyke ende Broederlyke 
Liefde, lasterd en veroordeeld ende zulks niet alleen ten aanzien van deszelvs uitterlyk Leeven en Comportement, maar ook (dat alleen Goode toekomt) ten aanzien van deszelvs herte, en inwendige Godsdienst voor den Heere.

Alle hetwelke, ende diergelijke zaaken meer, bij den kerken raad in de vreeze des Heeren zynde overwoogen, alhouwel se tegen zodanige publicque ergenissen ende misslagen zwaarder zouden kunnen procedeeren, insiende evenwel deszelvs hoogen ouderdom ende andere goede consideratien, so is 't dat J. J. Calckmann hier op voor den kerkenraad hebbende Christelyke Satisfactie gegeeven wat verklaaringe van ende onderteekeninge mits deesen, van te acquiesceeren in deszelvs uitspraeke of zyn meergen. Boeksken ende belofte van zig in toekomende voorzigtiger te zullen gedragen de zaeke allerwegen is en blijft afgedaan, vergeeten en vergeven.

(Onder stond) Jan Janz. Galckman. 